\title{
The Effect Social Environment of the Switching Intention on Social Media Facebook
}

\author{
Safira Rahmalia, Bambang Widjajanta, Girang Razati \\ Faculty of Economic and Business Education \\ Universitas Pendidikan Indonesia \\ safira.rahmalia@student.upi.edu
}

\begin{abstract}
The younger generation experiencing exhaustion using social media and tend to reduces frequency login them to social media. Even often move from one social media other social to the media. The decline in users who quite high caused, market share facebook continues to decrease from year to year.Previous studies show that social environment directly the impact of customers switching intention, this paper examine social environment factor that affect user intention to switch social networking sites and knowing about the influence of social environment on switching intention of Facebook users in member HIPMI University in Bandung. We propose and test a reseacrch model with 120 responses from member of HIPMI University in Bandung- Indonesia. Methods used the explanatory survey. Data collection was carried out by using a questionnarie. The reseach model suggest that social enviroment consist of family infuance, information resources, non-comercial resources and social class Had an impact of 46,4 \% on an individual switching intention. So that it can be said that social environment give a major impact on switching intention. Finally, we made a discussion in this finding as well as limitation and future study.
\end{abstract} Media

Keywords- Social Enviroment, Switchimg Intention, Social

\section{INTRODUCTION}

An increasing number of internet usage indicates that the internet has become part of the everyday life of society Indonesia. The community already knows the internet will always use the internet in any activities (1) it makes the development of competitive technologies at this point has contributed a large in the business world, employers utilize technology as a strategy to achieve the goal (achieving maximum profit). Thus the marketers have to be smart in taking action on technology development that occurred dimasyarakat. The modern era at this time made the technology becomes one of the results of human culture, because technology had been on one of the needs (2)

Technological developments make the emergence of various instant messaging applications are currently experiencing growth significantly. The growth of this instant messaging application rated can affect users of social media like Facebook, Twitter, Google +, Instagram, and other social media. This instant messaging application development to make the younger generation began to experience fatigue bersosial media and tend to reduce the frequency of their login to social media. Facebook is one of the social media users who decline quite significantly especially among teenagers. Global Web Index published a research report on users of social media in 32 markets globally. This research includes 170 thousand internet users. This study was conducted to examine the behavior of digital internet users today.

The decrease in users on Facebook are caused by more and more users who started to leave Facebook and prefer turning to social media to a new and more attractive to users of social media in Indonesia. The last few years, there has been an increasing number of social media where users can publish and share personal stories, opinions, knowledge, expertise, and product reviews. Users or consumers have the characteristics and the degree of difference in terms of selecting and using social media. An astute companies will try to understand our customers or consumers, having regard to the stage before making the decision to use such experience in learning, choosing, using, and disposing of or are not using the back (3). Hal tersebut menyebabkan penyedia layanan social media has a challenge to keep users and prevent users from switching to other social media. Some research suggests that switching intention has become a major concern for the social media service providers at this time.

Social media has become the community's way of communicating and also have an impact on the way companies do business. Social media services like Facebook, Twitter, LinkedIn or other social media sites are still significant role in the way companies do business online service marketing (4). Online business can be done either individually or in groups. Businesses need an association or assembly to exchange information and experience. One of the young businessmen's Association is HIPMI University Bandung however, most of HIPMI members PT Bandung rarely conduct business online on his Facebook account. Based on the prapenelitian indicates that desire (intention) to switch from social media is Facebook. The decline resulted in a fairly high users, Facebook market share continue to experience persempitan from year to year. Previous research shows that the attitude of social pressure directly impact customer switching intention (5).

Consumers created by their environment and also operate within the environment. Their decision process behavior is influenced by culture, social class, grups and families. The influence of the social environment as the level where the user online to see that important people believe they should be using 
social media. Social influence can cause the perceived pressure to do a particular behaviours, which reflects the extent to which individuals involved with social networks that may affect the use of each other's intentions (6). Social influence in the use of Facebook is concerned with the influence of important people in the life of users to continue to use these social media services. Some people are important to users is friends, family, a character role model, artist's Idol, and the environmental community. The presence of fan pages and applications users to interact much more encouraging this social environment influences the incidence of getting high and expected to suppress switching intention on Facebook users

These conditions demand a Facebook for more serious regard for the needs and desires of the users. Understanding of consumers should be an important element because by knowing precisely the needs and desires of its customers, the company will be able to provide products and services with superior quality as desired by its customers so as to make customers comfortable and have no intention to move. But differences with the research by previous research the previous penelitian-penelitian generally discusses switching intention theoretically mengggunakan teori-teori supporting research different, considering reference use also different .Perbadaan next is about faktor-faktor that can affect switching intention .Other differences located on an object research, writer research on social media industry, while some previous studies melakuakan research different objects as research on boarding house, the application of instant messaging and research on social network games. The study was also differs from previous studies .To research this time, researchers used the influence of social environment consisting of four the family affluence dimension, a source of information, non commercial source, and social class of switching intention Thus, this research aims to find out about the switching level picture intention Facebook users at a member of HIPMI Perguruan Tinggi Bandung.

\section{SWITCHING INTENTION ON SOCIAL MEDIA}

The influence of globalization have an impact on some of the things in the field of business, and the one that benefits from this is consumers. Consumer needs can be met and even have more alternatives in determining the products to meet their needs. Competition among the companies getting heavy, therefore the company is attempting to retain existing customers so loyal in the company and has no intention to switch (7).

The intention related to attitudes and behavior. The intention of indicating how far someone has the will to try (8). Furthermore the intention can be defined as the measurement of the will of a person and deals with the behavior of the continuous (9). Switching intention is the opposite side with the decision to buy or fidelity on the company. Switching intention can also be described as the degree of likelihood or certainty that a customer will switch from the current provider to the new provider (10).

Switching intention is the intention of the consumer to stop using services that are being used and switch to other services or customer wishes to terminate the degree has to do with service providers (11). Another opinion clarified the intention as the level switching possibility or certainty that a customer will switch from service providers or current products to new products or service providers (12). Similar with the other research stated that switching intention as a possible of consumers will do the transfer of services that are being used to service more (13)

The company is not enough to just attract new customers but the company must also be able to retain its customers and avoid switching intention because many companies that suffer losses due to lost customer (14). Losing customers is a serious threat to the company and it will affect the profits of the company. then, the company has to keep its customers so customers do not have the intention to switch. Switching intention on every consumer could not be equated with each other because this behavior depends on the satisfaction felt by the consumer (15).

Switching intention is divided into two, namely switching intention internally and externally. Where switching internal intention is an intention the transfer of customers happening but still within the scope of the same company. Type of switching intentiontersebut generally still profitable because the company is still in the same company albeit in different units. While switching the external intention is the intention to transfer customers to alternative service providers outside of the company (5)

From some of the above definition can be said that the switching intention is the possibility of consumer to switch from one company to another company. This may happen if the company does not meet the needs of the consumer, then the consumers can switch to competitors. Switching intention is divided into two i.e. switching intention internally and externally. Where switching internal intention is an intention the transfer of customers happening but still within the scope of the same company. While switching the external intention is the intention to transfer customers to alternative service providers outside of the company. The company must perform some strategies that aim to facilitate the acceptance in consumer to use technology and foster an intention to use the products offered (16)

The high level of competition in business world, making business more serious attempt to pay attention to the needs and desires of the customer. Subjective norm refers to existing pressures on the environment surrounding the perceived performance of social behavior. In this study, the subjective norm refers to the State of the social environment of the user against the perceived switching intention (17). The reason for the direct effect of the pressure of the social environment against the intention is that people can choose to do the behavior, if they are motivated to comply with important references (18). Previous research shows that the attitude of the social pressure felt by the user can directly impact customer switching intention (5). A strong social pressure makes the individual may need approval from colleagues who are considered essential to perform a particular behaviours will dictate when a decision (19) 
Social environment refers to the extent to which social media users believe that socialization needs of demanding users to move from one social media to other social media (20). The influence of the social environment is regarded as an important factor in the adoption of new technologies. In the context of social media, the influence of the social environment is defined as the influence of friends who have moved into social media alternatives and invite members to join the social media. Most social media provides functions such as automated email invitations and suggestions from friends who may user know to encourage users to invite other friends to join and leave the previous social media .

\section{RESEARCH METHOD}

The unit of analysis was made of the respondents in this research is a member of HIPMI PT Bandung. Therefore examined the level of switching intention on members of HIPMI Bandung. Methods used the explanatory survey. Data collection was carried out by using a questionnarie. This research was done in a span of less than one year, then the method used is cross sectional method, the collection of information from the subject only performed one time in one period of time, so this research is a one-shot or cross sectional.

The population in this research is a member of HIPMI PT Bandung by 2015-2016 as much as N: 355 members. The taking of sampling using simple random sampling from the population numbers and using the formula of Harun Al Rashid obtained samples as many as 120 members.

\section{FINDINGS AND DISCUSSIONS}

Based on the results of the social environment variable obtained that items statement (indicators) that reflects the highest is in dimension class sosialyang assessed by members of hipmi pt bandung 33,01\%. While the lowest dimension in dimension family affluence of $12,34 \%$. Judgment to the indicators the social class had been recognised by members pt bandung hipmi with the score at 2.694 this. The lowest indicators is in dimension family affluence because many members HIPMI PT Bandung need advice from someone who also has considerable experience mature in these areas in addition, the family were often support the decision taken by members HIPMI PT Bandung.

The Recapitulation of the variable switching intention obtained that items statement ( indicators ) that reflects the highest is in dimension propensity to switch assessed by members of hipmi pt bandung 74,02 \%.While the lowest dimension in dimension additional internal response to the problem $8,58 \%$.Judgment to the indicators propensity to the switch had been recognised by members pt bandung hipmi with the score at 4.953.The lowest indicators the internal dimension response to the problem because many members hipmi pt bandung doubts to make decisions own and still need to be the recommendation or saran-saran of the neighborhood social to determine choice.

Based on the results of research on the influence of the social environment towards the switching intentions on social media Facebook for business gain conclusion the social environment that has a strong connection with the aim of switching. The magnitude of relationships that occur are shown with the value of the correlation between the social environment with the intention of turning the result 0.681 (positive) it is in accordance with the interpretation of the figures against a coefficient of correlation (Sugiyono, 2013:95) then the relationship between the social environment against switching categories including strong intention (0.60-0.799) and the Standard Error of Estimate (SEE) by switching intention variables is 6.857 .

The figures are based on standard deviation (STD) figures showed the intent this number is 9.325 switch is larger than the figures SEE switching intentions 7636 this meaning (SEE) are good to use as a predictor of switching in determining intention, in which a good number to serve as predictor variables depends must be smaller than standard deviation (SEE < STD), the smaller the view will make increasingly precise regression in predicting variable depends.

Based on a simple linear regression equation above, the values of the constants 25,797 stated that if there is no improvement in the social environment $(X=0)$, then the magnitude of switching 25,797 intentions. Regression coefficient on the social environment variable is the value of one unit of the social environment increases mean 0450 will increase switching intentions 0450 a unit value and vice versa if the decline in the social environment, it will lower the value of 0450 switching intentions are one unit.

Impact on the social environment directly or simultaneously against switch intention, namely amounting to $46.4 \%$ while the influence of other variables that are not included in this study 53,6\%. In accordance with the results of research carried out by (21) says that the social environment had a significant influence on the switching intention. So that it can be said that social environment give a major impact on switching intention. Here is the recap of the influence of the social environment against switching intention in Figure I.

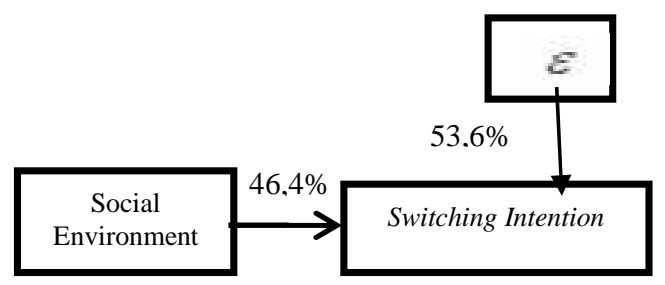

Fig. 1. The Effect of Social Environment of the Switching Intention

\section{CONCLUSION AND SUGGESTIONS}

The social environment has a positive effect against switching intention with strong correlation level. This shows that the greater the pressure of social environment will be increasingly higher switching HIPMI members of intention PT Bandung in using Facebook to support the activities of its business.

Based on the results of the research, then the authors recommend Social Media Facebook should improve features that can support the activities of a business users so that, users 
feel confident to continue doing business using social media is Facebook. Sosia media Facebook should improve the service, features, design social media Facebook so, make a lot of users come back again using Facebook and social media users who have returned to the Facebook group may recommend reference. Social media Facebook should also improve the services should be based on social needs of users, providing an interesting features and services can support the activities of the business. So it does not become an obstacle for the members HIPMI PT Bandung to keep using Facebook as a medium for doing business online. Provide experience and product development based on social needs of users will drive users to increasingly use social media Facebook to support the business activities of member HIPMI PT Bandung.

\section{REFERENCES}

[1] 1. Rahayu A, Wibowo LA. Analisis Nilai Pengalaman Berbelanja Online Melalui Experiential Marketing. J ilmu Manaj dan bisnis. 2013;04(01):1-15.

[2] 2. Yuliana, Tarmedi E. Pengaruh perbedaan individu terhadap keputusan menggunakan sistem operasi linux. J Bus Manag Educ. 2016;1(1):174-80.

[3] 3. Aprilia L, Wibowo LA. Pengaruh Faktor Individu dan Sosial teradapt Keputusan Menggunakan. J Bus Manag Educ. 2016;1(1):20212.

[4] 4. Supradono B, Hanum AN. Peran Sosial Media untuk Manajemen Hubungan dengan Pelanggan pada Layanan E-Commerce. J unimus. 2011;7(2):33-45.

[5] 5. Bansal HS. "Migrating" to New Service Providers: Toward a Unifying Framework of Consumers' Switching Behaviors. J Acad Mark Sci [Internet]. 2005 Jan 1;33(1):96-115. Available from: http://link.springer.com/10.1177/0092070304267928

[6] 6. Sheng, Margaret L. et al. The asymmetric - effect of online social networking attribute-level performance. Industrial Management \& Data Systems. 2011.Vol. 111 No. 7

[7] 7. Fitriansyah KA, Hurriyati R. Analisis Kinerja Interpersonal Relationship terhadap Customer Loyalty ( Survei pada Pelanggan Telkom Speedy di Kota Bandung ). J Bus Manag Educ. 2016;1(1):1-5.

[8] 8. Kaur G, Sharma RD, Mahajan N. Exploring customer switching intentions through relationship marketing paradigm. Int J Bank Mark. 2012;30(4):280-302.
[9] 9. Liu F, Xiao B. A Theoretical Model and Empirical Investigation of Social Networking Site Users ' Switching Intention. PACIS 2013 Proc. 2013;Paper 75.

[10] 10. Xu YC, Yang Y, Cheng Z, Lim J. Retaining and attracting users in social networking services: An empirical investigation of cyber migration. J Strateg Inf Syst [Internet]. 2014;23(3):239-53. Available from: http://dx.doi.org/10.1016/j.jsis.2014.03.002

[11] 11. Kuruuzum A, Deniz KC. the Impact of Service Quality on Behavioral Intention in. Int J Bus Manag Stud. 2010;2(1):9-15.

[12] 12. Saeed A, Riaz A. Factors Affecting Consumers 'Switching Intentions. Eur J Soc Sci. 2011;19(1):54-62.

[13] 13. Liza Agustina Maureen Nelloh, Carolina Chandra Purwanto Liem. Analisis Switching Intention Pengguna Jasa Layanan Rumah Kos Di Siwalankerto: Perspektif Kualitas Layanan Dan Kepuasan Pelanggan. J Manaj Pemasar [Internet]. 2011;6(1):22-31. Available from: http://puslit2.petra.ac.id/ejournal/index.php/mar/article/view/18387

[14] 14. Kotler P, Keller K, Brady M, Goodman M, Hansen T. Marketing management. [Internet]. 2016. 1022 p. Available from: http://eprints.lancs.ac.uk/29662/

[15] 15. Rizwan M, Ali M. Antecedents of Customer Switching Intentions : A case study of Nokia Mobile Phones' users. J public Adm goverment. 2013;3(3):375-91.

[16] 16. Haekal A, Widjajanta B. Minat Membeli Secara Online pada Pengunjung Website. J Bus Manag Educ. 2016;1(1):181-93.

[17] 17. Liao, C., Chen, J. L., \& Yen, D. C. Theory of planning behavior (TPB) and customer satisfaction in the continued use of e-service: An integrated model. Computers in Human Behavior, 2007. 23(6),pp: 2804-2822.

[18] 18. Venkatesh, V., \& Davis, F. D.A theoretical extension of the technology acceptance model: Four longitudinal field studies.Management Science. 2000. 46(2), 186-204

[19] 19. Gabriella Gall and Fredrik Olsson. How do the predictors of switching intention influence switching behavior?. Umeå School of Business and Economics. 2012

[20] 20. Xiaoyu Xu., Hongxiu Li., Jukka Heikkila., dan Yong Liu. Exploring Individuals Switching Behavior: An Empirica Investigation In Socal Network Games In China. 2013.

[21] 21. Stephanie Polinar., Hong Joo Lee., dan Jaewon Choi. Switching Intention Between Networking Sites: Exploring The Philipine Case Of Friendster VS Facebook, Journal of the Society of Korea-party transactions. 2013.Vol 3, No 18 